
Arditya Prayogi

\title{
Pendekatan Kualitatif dalam Ilmu Sejarah: Sebuah Telaah Konseptual
}

\author{
Arditya Prayogi \\ IAIN Pekalongan \\ arditya.prayogi@iainpekalongan.ac.id
}

\begin{abstract}
The popularity of the qualitative approach has recently increased. Especially in the social sciences (including the humanities), where this approach has its own place, although, the most important substance in science, namely the theory itself, is actually qualitative. This is further strengthened by the essence of a qualitative approach (in the social sciences of the humanities) which emphasizes the investigation of a social phenomenon and human problem. This article describes how a qualitative approach is used (particularly) in the science of history, as well as the various characteristics inherent in qualitative research which is so closely related to the science of history. This article was written using descriptive analytical method supported by literature study as the data mining process. From the results of the description, it is known that history as a family of humanities will inevitably (still) use a qualitative approach in its scientific description. This qualitative approach is in the form of a narrative-descriptive-analytical explanation of history, which makes history, apart from being a science, also a story. The task of history is to tell stories through narrative texts, so that a qualitative approach is embedded in the science of history. Keywords: Approach, Qualitative, Historical Science
\end{abstract}


Pendekatan Kualitatif dalam Ilmu Sejarah: Sebuah Telaah Konseptual| Arditya Prayogi

\section{Pendahuluan}

Diskursus mengenai pendekatan keilmuan, secara umum sering digambarkan dalam pengkutuban antara ilmu Pengetahuan Alam dan Ilmu Kemanusiaan (Ilmu Sosial/Humaniora/Budaya). Jika di satu kutub Ilmu Pengetahuan Alam, proses pengambilan kesimpulan (generalisasi) dilakukan melalui proses analisis-kuantitatif, maka, di kutub yang lain, Ilmu Kemanusiaan, mengambil kesimpulan melalui rumusan analisis melalui proses deskriptif-kualiatif. Dalam hal ini, pendekatan kualitatif yang (banyak) digunakan dalam ilmu-ilmu kemanusiaan (akhirnya) sering mendapat pandangan sebagai sesuatu yang tidak objektif atau subjektif. Hal demikian menjadi problematis, baik dalam pengembangan ilmu-ilmu kemanusiaan pada umumnya serta salah satu bidang dalam ilmu-ilmu kemanusiaan. Problematisasi ini terutama didasari pada objek studi dalam ilmu-ilmu kemanusiaan (soshum), yaitu manusia itu sendiri, dimana selain sebagai objek kajian sekaligus juga menjadi subjek kajian. Dengan posisi yang demikian, "tuduhan" bahwasanya ilmu-ilmu kemanusiaan sesungguhnya adalah "bukan ilmu" menjadi semakin kentara. Kedudukan yang demikian berbeda dalam ilmu-ilmu alam (eksakta) yang menjadikan benda tak hidup (objek) hanya sebagai objek yang jelas-jelas memiliki jarak yang jauh dengan peneliti (manusia) sebagai subjeknya, sehingga ilmu-ilmu alam sering dipahami sebagai ilmu yang objektif. Meski pada akhirnya, bias ukur yang digunakan lebih mengarah kepada tolak ukur keilmiahan ilmuilmu eksakta atau ilmu pengetahuan alam, yaitu dalam hal ke-obyektifannya.

Puncak aliran rasionalisme yang berujung pada fase positivisme (walaupun terdapat banyak cabang didalamnya), pada medio abad ke-18 dan 19, menjadi latar utama timbulnya diskursus mengenai standar keilmuan. Latar demikian menggambarkan bagaimana kemajuan Ilmu Pengetahuan Alam kemudian menjadi "hakim" dalam penentuan standar apakah suatu cabang ilmu -secara normatif, dikategorisasikan sebagai "ilmu", dengan menggunakan kriteria dalam kemampuannya membuat generalisasi dan memprediksi masa depan yang terhubung dengan kemampuan merumuskan dalil atau hukum (alam). Atas dasar inilah kemudian ilmu-ilmu kemanusiaan atau sosio-humaniora (Sejarah, Filsafat, Antropologi, dan lain sebagainya) dikategorisasi menjadi bukan "ilmu" dikarenakan tidak adanya kemampuan 
Pendekatan Kualitatif dalam Ilmu Sejarah: Sebuah Telaah Konseptual| Arditya Prayogi

"merumuskan dalil atau hukum". ${ }^{1}$ Hal ini juga diperkuat dengan anggapan bahwa karya ilmiah haruslah mengeyampingkan sisi kemanusiaan dan bersifat ajeg. Walhasil, penelitian yang melibatkan manusia sebagai objeknya (ilmu kemanusiaan) dianggap (hanya) memiliki daya "penghibur", sehingga hasil penelitian sosial lebih diklaim sebagai karya sastra semata dan berakhir menjadi tidak ilmiah. Meski, pada perkembangannya kemudian terjadi peleburan antara karya fakta dan fiksi menjadi sebuah karya ilmiah yang terjadi belakangan, yang terjadi kurang lebih pada abad ke-20. ${ }^{2}$

Sebagai jalan keluar maka muncul dua pendekatan, yang masingmasing ingin berdiri dengan jalan/metode keilmuannya sendiri, serta mengawinkan antara kedua metode ini. ${ }^{3}$ Pendekatan/metode kualitatif, dikembangkan sebagai sebuah cara untuk mengkaji kehidupan manusia dalam kasus-kasus yang terbatas, namun holistik karena semakin demokratik dan "people centered"-nya kehidupan manusia. Pendekatan ini juga dikembangkan sebagai suatu upaya untuk mengungkapkan berbagai gejala dalam kehidupan masyarakat seperti yang terefleksikan dalam kehidupan warga masyarakat itu sendiri, yang bebas dari intervensi pengamat/peneliti. Dengan arah yang demikian, pendekatan kualitatif tidak mengizinkan berkembangnya perspektif konseptual dari sudut amatan para peneliti. ${ }^{4} \mathrm{Hal}$ lain yang juga terkait, bahwasanya, pendekatan/metode kualitatif dalam ilmu-ilmu kemanusiaan digunakan sebagai metode penelitian mengenai makna aksi individu dan berbagai interaksi antar individu yang terdapat dalam tatanan perilaku dan kehidupan manusia. Penelitian dalam ilmu-ilmu kemanusiaan didorong serta agar banyak menggunakan metode kualitatif sebagai paradigma teoretik yang rancangan metodologisnya amat berbeda dengan metode kuantitatif -di kutub yang lain.

Adalah sejarah sebagai salah satu kajian di bidang ilmu humaniora sendiri yang juga menjadikan objek manusia dalam masyarakat yang menjadi aspek penting penelitian seperti halnya juga disiplin-disiplin ilmu

\footnotetext{
${ }^{1}$ Watloly Aholiab, Tanggung Jawab Pengetahuan : Mempertimbangkan Epistemologi Secara Kultural (Yogyakarta: Kanisius, 2001), 55-87.

${ }^{2}$ Santana K. Septiawan, Menulis Ilmiah: Metode Penelitian Kualitatif (Jakarta: Yayasan Obor, 2007), 14-20.

${ }^{3}$ Rasyid A. Asba, Paradigma Baru Perkembangan Teori Dalam Ilmu Sejarah dan Arkeologi, Makalah Bulan Bahasa (Universitas Hassanudin, 2007), 1.

${ }^{4}$ Asba, 2.
} 
Pendekatan Kualitatif dalam Ilmu Sejarah: Sebuah Telaah Konseptual| Arditya Prayogi

sosial/humaniora lain. Yang diteliti dalam sejarah kemudian adalah kehidupan masyarakat -lebih khusus lagi individu manusia- yang menekankan pada aspek budayanya dalam kaitannya dengan aspek masa lalunya. Oleh karena itu, bidang kajian sejarah umumnya juga menggunakan pendekatan kualitatif seperti juga ilmu sosial-humaniora lainnya.

\section{Metode Penelitian}

Penulisan artikel ini menggunakan metode deskriptif analitis dengan berdasarkan penggalian data melalui metode studi pustaka/studi literatur dari beberapa sumber literatur (tertulis). Penulisan dilakukan melalui proses penggalian data dari berbagai sumber rujukan yang membahas berbagai artikel/tulisan terkait dengan berbagai literatur mengenani pendekatan kualitatif, terutama yang berkaitan dengan ilmu sejarah. Berbagai sumber ini dimuat di media publik, sehingga dapat diakses melalui beragam tempat (perpustakaan) dan media internet secara terbuka. Tulisan ini dapat menjadi elaborasi dari berbagai artikel dan tulisan yang terkait. Demikian pula, artikel ini lebih merupakan sebuah sintesis dari tulisan-tulisan yang pernah ada, untuk kemudian dilihat dalam hubungannya dengan apa yang dapat dilakukan dalam konteks saat ini.

\section{Hasil dan Pembahasan}

\section{Karakteristik Penelitian Kualitatif}

Ada banyak definisi mengenai pendekatan/metode kualitatif dalam studi literatur/pustaka, baik secara etimologis maupun terminologis. Atas dasar ini maka artikel ini lebih banyak mengulas karakteristik penelitian kualitatif yang mana dari beberapa karakteristiknya, maka dapat dikatakan sangat dekat dengan ilmu sejarah.

Natural setting atau (pendekatan) penelitian naturalistik, adalah istilah lain metode penelitian kualitatif. Hal ini karena proses penelitiannya dilakukan pada kondisi yang alamiah, tanpa menggunakan alat bantu ukur dan menjadikan kondisi alamiah sebagai wilayahnya. Selain itu, penelitian kualitatif dikenal pula dengan metode etnografi, ${ }^{5}$ Penggunaan istilah ini

\footnotetext{
${ }^{5}$ Istilah penelitian kualitatif memang dikenalkan dalam beberapa metode keilmuan. Dalam hal ini ada lima bidang kajian yang kemudian menggunakan metode penelitian kualitatif yakni etnografi, biografi, studi kasus, fenomenologi, dan grounded theory (J.R.
} 
Pendekatan Kualitatif dalam Ilmu Sejarah: Sebuah Telaah Konseptual Arditya Prayogi

sangat terkait erat dengan penelitian bidang antropologi budaya ${ }^{6}$ yang mana berbagai data yang terkumpul dan disajikan tidak menggunakan modelmodel matematik, statistik atau komputer ${ }^{7}$, namun menggunakan deskripsi kata/kualitatif.

Penelitian kualitatif memiliki objek kajian berupa seluruh aspek dalam kehidupan manusia, yakni manusia dan segala hal yang dapat dipengaruhi oleh manusia. Untuk itulah maka penelitian kualitatif menjadi sangat dekat dengan bidang ilmu-ilmu kemanusiaan, seperti yang telah disampaikan sebelumnya. Penelitian kualitatif menghimpun data berbagai aspek dalam kehidupan manusia, baik sejarah, hukum, agama, ekonomi, dan lain sebagainya, digambarkan dalam bentuk kalimat, yang diolah melalui proses logika kritik-analitik-sintetik hingga tuntas. Penelitian kualitatif mengungkap kondisi alamiah sebagaimana adanya melalui pola berpikir yang runut, teratur, tertib, dan cermat, serta menghubungkan berbagai data satu dengan lainnya dan konteks dalam problematika yang akan diungkap. Penyusunan aturan berpikir serta menyusun asumsi dasar menjadi tahap awal untuk memulai proses penelitian kualitatif. Penelitian kualitatif, jika dipahami secara ringkas, akan berangkat dari sebuah data, yang kemudian akan dianalisis menggunakan sebuah teori dan akan menghasilkan kembali sebuah teori. $^{8}$

Secara sederhana dapat pula diartikan bahwa data berupa kalimat (tidak melibatkan angka) dalam proses pengumpulan informasi serta proses

Raco, Metode Penelitian Kualitatif: Jenis, Karakteristik, dan Keunggulannya (Jakarta: Grasindo, 2007), 37-38.)

${ }^{6}$ Walau memiliki berbagai jenis, penelitian kualitatif yang digunakan dalam ilmu sosial/humaniora memiliki kesamaan berupa adanya pengalaman manusia didalamnya, melihat peristiwa secara holistik, ditujukan untuk mencari arti serta makna, mencari hakikat dari sebuah peristiwa, mempelajari pengalaman manusia yang tidak dapat dikuantifikasi, bersifat subjektif, serta menuntut adanya peranan penting dari subjek peneliti (Raco, 52-55.)

${ }^{7}$ Ada banyak definisi terkait penelitian kualitatif. Diantaranya mengartikan bahwa penelitian kualitatif adalah prosedur penelitian yang menghasilkan data deskriptif berupa kata-kata tertulis atau lisan dari orang-orang dan perilaku yang dapat diamati. Dalam bahasa yang sederhana dapat disimpulkan bahwa penelitian kualitatif adalah penelitian yang menghasilkan temuan yang tidak menggunakan prosedur statistik atau cara-cara lain dari metode kuantitatif (Puput Saeful Rahmat, "Penelitian Kualitatif," Jurnal Equilibrium 5, no. 9 (2009): 2.)

\section{${ }^{8}$ Rahmat, 5.}


Pendekatan Kualitatif dalam Ilmu Sejarah: Sebuah Telaah Konseptual| Arditya Prayogi

penafsirannya merupakan aktivitas inti dalam penelitian kualitatif. Dalam hal ini, penelitian kualitatif pun memiliki karakteristik tersendiri antara lain,

a. Lingkungan alamiah menjadi titik tekannya. Artinya, data didapatkan serta berada di tempat dimana penelitian itu akan dibuat. Dalam hal ini juga peneliti menjadi terlibat langsung dalam seluruh proses pengolahan data didalamnya. Untuk memeroleh lingkungan alami, juga diperlukan penyatuan dari berbagai perspektif hingga dapat memunculkan satu kesatuan gambaran.

b. Bersifat induktif dan fleksibel. Hal ini berarti penelitian kualitatif akan dimulai dari hal-hal spesifik menuju hal-hal umum atau mencari generalisasi. Sifat induktif akan lebih memperhatikan fakta empiris daripada hipotesa. Selain itu dengan sifat fleksibel, penelitian kualitatif tidak menutup diri dari ditemukannya teori-teori baru, sehingga sifat kelimuannya tidak menjadi kaku. Hal ini akan terus memicu munculnya kreativitas dalam menjalani sebuah penelitian.

c. Adanya "masalah" merupakan pijakan awal dimulainya Penelitian Kualitatif. Masalah adalah suatu kesenjangan (discrepancy) antara apa yang seharusnya (das sollen) dengan apa yang ada (das sein) dalam kenyataan atau antara apa yang diperlukan dengan apa yang tersedia atau antara harapan dengan kenyataan. Dalam penelitian kualitatif "masalah" yang dibawa oleh peneliti masih remang-remang, bahkan gelap, kompleks dan dinamis. Oleh karena itu, "masalah" dalam penelitian kualitatif masih bersifat sementara, tentatif dan akan berkembang atau mungkin berganti setelah peneliti berada di lapangan. Secara mudah, rumusan masalah dalam penelitian kualitatif diawali dengan kata tanya why (mengapa) dan how (bagaimana), tidak sebatas what (apa), who (siapa), when (kapan), dan where (dimana).

d. Peneliti turut pula mengambil bagian menjadi instrumen penelitian di dalam penelitian kualitatif. Berlangsungnya proses pengumpulan data dalam penelitian kualitatif, peneliti diharapkan mampu berinteraksi dengan obyek (masyarakat) yang dijadikan sasaran penelitian. Keberhasilan dalam penelitian kualitatif sangat terkait erat dengan apa yang didapat melalui proses seksama pencatatan informasi dari lapangan (data lapangan). Dengan 
Pendekatan Kualitatif dalam Ilmu Sejarah: Sebuah Telaah Konseptual| Arditya Prayogi

kata lain, Peneliti haruslah memiliki kepekaan dalam menangkap berbagai gejala menggunakan pendekatan alamiah. Ketidakcermatan dalam menangkap berbaga data lapangan akan berakhir pada sulitnya proses analisis dalam pengambilan kesimpulan yang nantinya justru merugikan peneliti sendiri. Beberapa hal penting yang perlu dikerjakan dalam proses penghimpunan data kualitatif antara lain; (1). Data hasil kontak dengan sumber dapat diringkas, (2). Simbol atau ringkasan digunakan sebagai kode, (3). Pembuatan catatan objektif, klasifikasi dan mengedit data, (4). Mencatat secara reflektif, (5). Komentar dibuat dalam catatan marginal, (6). Penyimpanan data, (7). Menganalisis proses penghimpunan data, (8). Analisis antar lokasi. ${ }^{9}$

e. Berproses dari pengalaman langsung. Data yang dihasilkan dalam penelitian kualitatif memunculkan karakter bahwa data tersebut merupakan pengalaman langsung dari para pelaku/partisipan. Dengan menjadi sebuah pengalaman langsung, maka data merupakan hasil dari tangan pertama para pelaku, dan menghindari terjadinya subjektivitas yang terlalu tinggi.

f. Membutuhkan kedalaman sumber dan deskripsi yang jelas (indepth). Penelitian kualitatif akan bersifat deskriptif dan menghasilkan data berupa sebuah teks untuk dibaca dan diharapkan dapat menggambarkan situasi dengan jelas sehingga dapat memengaruhi pembaca dan pembaca seolah-olah juga dapat merasakan langsung. Proses deskripsi akan membutuhkan kekuatan teks sehingga membutuhkan adanya kedalaman sumber, yang berarti dapat mengerti bagaimana orang memahami sesuatu.

g. Penelitian kualitatif memiliki ciri berupa pendalaman terhadap data yang telah dikumpulkan. Pendalaman (indepth) dibutuhkan untuk menentukan fokus penelitian. Sebelum merumusan fokus penelitian, peneliti terlebih dahulu melakukan pendalaman terhadap topik tersebut. Hal yang menarik untuk diteliti atau isu yang menarik perhatian peneliti dari topik tersebut dan akan diperoleh jawabannya melalui proses penelitian dalam proses pendalaman ini. secara 35.

${ }^{9}$ Syukur Kholil, Metode Penelitian Komunikasi (Jakarta: Gramedia, 2006), 120- 
Pendekatan Kualitatif dalam Ilmu Sejarah: Sebuah Telaah Konseptual| Arditya Prayogi

sederhana upaya pendalaman akan menghasilkan topik dan juga metode penelitiannya. Hal ini penting agar penelitian yang dilakukan tidak keluar dari jalur yang telah ditetapkan.

h. Berlangsungnya proses penelitian kualitatif, harus sejalan dengan munculnya keabsahan. Keabsahan data kualitatif harus dilakukan sejak awal pengambilan data, yaitu sejak melakukanreduksi data, display data dan penarikan kesimpulan atau verifikasi. Untuk memperoleh keabsahan data (check dan re-check) dilakukan berbagai cara untuk menjaga kredibilitas, ${ }^{10} \operatorname{transferabilitas}^{11}$ dan dependabilitas. ${ }^{12}$

i. Lebih mementingkan proses, dimana dinamika terjadinya peristiwa akan lebih disoroti daripada hasil dari peristiwa itu.

j. Dapat menangkap arti/makna. Penelitian kualitatif harus dapat menangkap makna dari sebuah peristiwa. Tafsiran/intepretasi yan dilakukan oleh peneliti juga harus didukung dengan data yang kuat sehingga makna yang muncul dapat menjadi sebuah generalisasi.

k. Bersifat holistik. Sifat induktif dari penelitian kualitatif mensyaratkan bahwa penelitian yang dilakukan harus mencakup berbagai aspek secermat dan selengkap mungkin agar mampu menutup segala celah yang mungkin akan timbul.

10 Menjaga kredibilitas dapat dilakukan dengan: a). Observasi dalam waktu cenderung panjang, b). Pengamatan secara intens, c). Data yang ditrianggulasi, d). Orang lain menjadi objek yang dibicarakan (peer debriefing), e). Analisis kasus negatif, f). Penggunaan berbagai bahan referensi, dan g). Mengadakan member check.

11 Transferabilitas sangat berkaitan dengan masalah generalisasi, dalam artian sejauh mana batas suatu generalisasi dapat berlaku bagi berbagai kasus lain di luar penelitian. Penelitian kualitatif tidak memberikan jaminan atas keberlakuan hasil penelitiannya pada subyek lain. Hal demikian disebabkan karena tujuan penelitian kualitatif bukanlah untuk menggeneralisir, mengingat penelitian kualitatif tidak menggunakan sampling acak, kerena bersifat pursosive sampling.

12 Dependabilitas (atau disebut pula "reliabilitas instrumen") merupakan indeks yang memperlihatkan sebatas mana suatu alat pengukur dapat diandalkan atau dipercaya. Indeks reliabilitas dapat memperlihatkan hingga sejauh mana suatu hasil dalam proses pengukuran dipercaya/konsisten jika dikalibrasikan terhadap gejala yang sama dengan alat yang juga sama. Maka, "reliabilitas" ini dilakukan dengan teknik check and recheck. Faktor subyektivitas harus dapat diminimalisir oleh peneliti sehingga muncul obyektivitas melalui indikator berupa pem-benar-an atau proses "confirm" oleh peneliti lain. Dari sinilah obyektifitas menjadi identik dengan istilah "confirmability". 
Pendekatan Kualitatif dalam Ilmu Sejarah: Sebuah Telaah Konseptual| Arditya Prayogi

1. Terdapat partisipasi aktif dari partisipan dan adanya penafsiran. Adanya partisipasi aktif dari subjek dan objek penelitian merupakan hal yang tidak dapat dihindari untuk menjaga keilmiahan penelitian kualitatif. Penafsiran yang dilakukan juga tidak dapat dilakukan tanpa didukung data dan pemahaman yang tidak lengkap. ${ }^{13}$

Dengan adanya karakteristik ini maka penelitian kualitatif memiliki keunggulan bahwa data yang dihasilkan merupakan data empiris atau berdasar fakta. Pembahasannya yang holistik dan sifatnya yang fleksibel memungkinkan penelitian kualitatif untuk terus berkembang. Penempatan manusia sebagai subjek dan objek didalamnya menjadikan manusia "ditempatkan" sebagaimana mestinya. Pendekatan kualitatif tidak menutup diri atas kelemahannya, namun pendekatan kualitatif dalam ilmu sosial humaniora masih relevan untuk terus digunakan dan tidak dapat dilepaskan sebagai sebuah keharusan, walau dewasa ini penggunaan metode gabungan berupa kuantitatif juga mulai dirasakan perlu untuk saling melengkapi satu dengan lainnya.

\section{Ilmu Sejarah dan Pendekatan Kualitatif}

Dalam ilmu sejarah, permasalahan data sejarah dan terutama intepretasinya, sering dianggap sebagai sesuatu yang "kurang ilmiah". Hal demikian memunculkan kesan bahwasanya ilmu sejarah bukanlah ilmu itu sendiri karena memiliki titik lemah utama sebagai ilmu. Ilmu sejarah akhirnya (sering) dipandang sebagai sebuah ilmu yang sangat subjektif. Kesubjektifan itu pada dasarnya merupakan sebuah keniscayaan jika mengacu pada definisi sejarah subjektif, dimana sejarah merupakan hasil (subjektifitas) para sejarawan. Dasar filosofis keilmiahan ilmu yang diukur dengan adanya "keajegan" tidak dapat ditemukan dalam sejarah karena sejarah itu unik dan terjadi hanya sekali.

Walaupun begitu, ilmu sejarah sebagai salah satu rumpun ilmu humaniora mau tidak mau (masih) akan menggunakan pendekatan kualitatif dalam deskripsi keilmuannya. Pendekatan kualitatif ini berupa penjelasan sejarah secara naratif-deskriptif-analitis, yang menjadikan sejarah selain sebagai sebuah ilmu juga sebuah cerita. Tugas sejarah adalah menceritakan

\footnotetext{
${ }^{13}$ Raco, Metode Penelitian Kualitatif: Jenis, Karakteristik, dan Keunggulannya,
} $56-62$. 
Pendekatan Kualitatif dalam Ilmu Sejarah: Sebuah Telaah Konseptual| Arditya Prayogi

kisah melalui teks-teks naratif, sehingga pendekatan kualitatif menjadi lekat dalam ilmu sejarah. Metode kualitatif digunakan dalam ilmu-ilmu sosial termasuk sejarah mengingat beberapa hal yang mesti dipertimbangkan lebih lanjut. Yang utama yaitu penggunaan metode kualitatif menjadi penting, karena metode kualitatif dalam ilmu sejarah dapat menghadapi kenyataan ganda yang muncul dalam ranah kehidupan manusia. Hal lain yang penting pula, metode kualitatif dalam ilmu sejarah dapat pula menggambarkan hakikat hubungan antara peneliti dan responden secara langsung, serta metode ini memiliki kepekaan untuk dapat beradaptasi dengan banyak penajaman pengaruh bersama dan terhadap pola-pola nilai yang dihadapi. ${ }^{14}$ Namun begitu, yang masih menjadi soal, apakah sejarah mampu untuk menjadi ilmu yang melahirkan suatu keajegan agar kemudian sejarah lebih bernilai sebagai ilmu. ${ }^{15}$ Untuk itulah akhirnya dalam sejarah dikenal dengan konsep generalisasi sejarah.

Generalisasi sejarah muncul sebagai jawaban atas tuduhan "ketidakilmiahan" sejarah sebagai ilmu. Para ahli sejarah memberikan jalan keluar, bahwa sifat sejarah memang tidak dapat didekati dengan pendekatan positivism. ${ }^{16}$ Berangkat dari hal ini, ahli-ahli ilmu sosial kemudian memberikan batasan masing-masing ilmu alam dan manusia dengan metode dan metodologi kelmuannya, walaupun berangkat dari sesama fakta empiris. Sejarawan menekankan bahwa suatu fakta empiris akan menjadi sejarah jika diobservasikan sehubungan dengan apa-apa yang tunggal dan individual. Pun begitu dengan proses kausalitas dalam sejarah, dimana sejarah hanya menilai suatu proses atau faktor-faktor yang berhubungan dengan kebudayaan historis. ${ }^{17}$

Sejarah adalah ilmu yang bersifat idiografis, kualitatif dan subjektif, sehingga menimbulkan kesulitan untuk mengilmiahkannya atau membuat generalisasi didalamnya. Namun begitu, kesulitan generalisasi ini dapat

\footnotetext{
${ }^{14}$ Helius Sjamsudin, Metodologi Sejarah (Yogyakarta: Ombak, 2007), 5.

${ }^{15}$ Asba, Paradigma Baru Perkembangan Teori Dalam Ilmu Sejarah dan Arkeologi, 6.

${ }^{16}$ Arditya Prayogi, "Paradigma Positivisme Dan Idealisme Dalam Ilmu Sejarah: Tinjauan Reflektif Terhadap Posisi Sejarah Sebagai Ilmu," Tamaddun: Jurnal Kebudayaan dan Sastra Islam 21, no. 1 (2021): 75-90.

${ }^{17}$ Sartono Kartodirdjo, Pemikiran dan Perkembangan Historiografi Indonesia : Suatu Alternatif (Jakarta: Gramedia, 1982), 48-50.
} 
Pendekatan Kualitatif dalam Ilmu Sejarah: Sebuah Telaah Konseptual| Arditya Prayogi

direduksi dengan adanya tingkatan dalam generalisasi sejarah (begitu juga ilmu sosial/humaniora), yakni generalisasi universal, dan generalisasi lokal. Atas dasar ini, generalisasi dalam sejarah merupakan sebuah istilah yang tidak sepenuhnya diterima, namun telah menjadi sebuah konsep. Sebagai ilmu yang menekankan kekuatan narasi/kualitatif, maka sejarah memiliki generalisasi yang dapat dijelaskan melalui pendekatan ilmu-ilmu sosial. Sejarah jarang atau tidak pernah mengalami sebuah keajegan yang menimbulkan dalil atau hukum universal. Dalam hal ini terdapat "konsep" yang dapat menjadi alat analisis generalisasi dalam sejarah seperti perubahan, revolusi, sebab akibat, dan sebagainya yang bisa dilihat dari berbagai historiografi yang ada. ${ }^{18}$

Dalam praktiknya, terdapat empat makna penting yang dimiliki dalam penulisan generalisasi sejarah yaitu covering law, silogisme, generalisasi sejarah, dan inferensi statistik. Yang pertama, covering law. Merupakan hukum universal yang berasal dari hukum ilmu alam. Hakikatnya sejarawan adalah ahli ilmu alam itu sendiri, dimana kausalitas sejarah itu haruslah dianggap sama saja dengan kausalitas ilmu alam, yang turut patuh pada hukum-hukum yang universal (general laws). Kedua, silogisme merupakan proses generalisasi empiris. Ketiga, generalisasi sejarah, adalah generalisasi yang dibuat dengan proses pembandingan berbagai unit sejarah. Terakhir, inferensi statistik, yang merupakan metode statistik, berupa distribusi, korelasi, regresi, content analysis, dan time series yang berakhir pada pembentukan generalisasi itu sendiri. ${ }^{19}$

Dengan sifatnya yang berupa eksplanasi, sejarah sebagai ilmu haruslah menghasilkan sebuah kesimpulan layaknya ilmu-ilmu yang lain. Metode sejarah yang bersifat kualitatif, akan membedakannya dengan ilmuimu alam, dimana jika ilmu alam akan menghasilkan teori atau hukum alam yang ajeg, maka sejarah akan menghasilkan generalisasi. Generalisasi merupakan efek dari salah satu karakteristik yakni induktif, dimana generalisasi mencari dalil umum yang ditarik dari peristiwa yang khusus. Generalisasi dalam sejarah dapat bertujuan untuk saintifikasi dan simplifikasi,

${ }^{18}$ Dadang Supardan, Pengantar Ilmu Sosial: Sebuah Kajian Pendekatan Struktural (Jakarta: Bumi Aksara, 2009), 351.

${ }^{19}$ Kuntowijoyo, Penjelasan Sejarah (Yogyakarta: Tiara Wacana, 2008), 97-98. 
Pendekatan Kualitatif dalam Ilmu Sejarah: Sebuah Telaah Konseptual| Arditya Prayogi

Secara sederhana, generalisasi adalah proses penarikan kesimpulan dari hal spesifik/khusus kepada hal yang general/umum yang dapat memunculkan dugaan sementara/hipotesis (yang deskriptif). Tujuan generalisasi sendiri mencakup dua hal; saintifikasi dan simplifikasi. Dalam sejarah, tujuan saintifikasi itu sendiri, menempatkan generalisasi dapat menjadi spesifikasi bagi ilmu lain, atau dalam posisi lain dapat dianggap menjadi "dasar teori"/grounded theory. Jika sejarah dipahami sebagai sebuah "teori" (atau menghasilkan teori) maka hal tersebut adalah "generalisasi" itu sendiri. Sedangkan simplifikasi, dilakukan agar sejarawan dapat melakukan analisis lebih jauh. Generalisasi sendiri terdiri dari berbagai bentuk antara lain, generalisasi konseptual, personal, tematik, spasial, periodik, sosial, kausal, kultural, sistemik, struktural, deskriptif, korelatif, dan kondisional. ${ }^{20}$

Meski demikian, dalam generalisasi, para sejarawan (sering) terjebak apabila generalisasi (justru) dianggap sebagai hukum umum yang pasti serta tidak representatif Padahal di sisi lain, ilmu sejarah itu bersifat induktif dan bukan deduktif. Untuk mempertanggung jawabkan keilmiahan sejarah sebagai ilmu dengan pendekatan kualitatif, maka seorang sejarawan harus mampu untuk mengumpulkan semua data yang relevan dengan pertimbangan yang definitif. Sejarawan juga harus menilai penuh setiap data yang dikumpulkannya dan melakukan usaha semaksimal mungkin untuk netral dalam wilayah yang ditelitinya Sejarawan juga harus mampu memberikan pertimbangan matang dan menghindari konklusi yang tidak logis dan tidak berdasarkan atas bukti. $^{21}$

Dalam sejarah dan sifat-sifatnya, pengungkapan keajegan dapat dieksplorasi dengan bantuan berbagai alat analitis dari ilmu sosialhumaniora. Pada titik ini juga muncul istilah "sejarah berulang", yang berarti memberikan suatu generalisasi berupa pola jalannya suatu proses. Dalam kajian sejarah dapat diberikan suatu contoh mengenai generalisasi dalam sebuah studi komparatif. Revolusi misalnya, dimana dalam segi substansialnya, tiap peristiwa revolusi merupakan hal yang unik, namun dalam segi formalnya akan mampu memunculkan generalisasi. Gerakan petani, dapat digeneralisasikan sebagai sebuah gerakan sosial, dengan aspek

\footnotetext{
${ }^{20}$ Kuntowijoyo, Pengantar Ilmu Sejarah (Yogyakarta: Bentang, 2001), 142-49.

${ }^{21}$ Louis Gottschalk, Mengerti Sejarah, Terj. Nugr (Jakarta: UI Press, 2006), 236-
} 38. 
Pendekatan Kualitatif dalam Ilmu Sejarah: Sebuah Telaah Konseptual| Arditya Prayogi

adanya ideologi sebagai penggerak, sifat revolusi yang berlangsung singkat, dan berakhir dengan kekerasan. Darisini sejarah dengan pendekatan kualitatif yang hanya mendeskripsikan sebuah peristiwa khusus saja, tanpa adanya sebuah generalisasi menjadi sebatas pemberitahuan fakta dan informasi semata. Namun dengan adanya penarikan induksi, generalisasi sejarah mampu memunculkan sebuah "dalil" atau hukum yang dapat mengembangkan sejarah sebagai ilmu lebih jauh. ${ }^{22}$

Hingga saat ini, pendekatan kualitatif (masih akan) menjadi kecenderungan yang digunakan dalam metode sejarah, walau masih terdapat kelemahan didalam pendekatan kualitatif. Kelemahan-kelemahan itu bersumber dari tidak adanya dasar-dasar pengukuran akan kebenaran data dan fakta sejarah yang jelas dalam berbagai instrumennya, serta tidak adanya pedoman-pedoman umum apalagi khusus, dalam teknik serta metode dalam menganalisis hubungan antar berbagai peristiwa sejarah, hingga analisis antar hubungannya lebih banyak ditentukan oleh intepretasi subjektif yang erat kaitannya dengan intuisi dan imajinasi sejarawan yang pengujian kadar kebenarannya sulit dilakukan secara empiris. Generalisasi dalam sejarah pun dianggap memiliki validitas yang terbatas dan tak dapat diklaim bahwa validitas serta intepretasi seorang sejarawan lebih unggul dari sejarawan lain. Atas dasar ini, para sejarawan haruslah mampu membedakan berbagai peristiwa yang "historicable" dan yang tidak. Untuk itulah pendekatan kualitatif dalam sejarah kemudian mengharuskan para sejarawan untuk menjadikan sejarah sebagai ilmu dengan berbagai cara yang harus dilakukannya.

\section{Simpulan}

Sebuah penelitian kualitatif pada dasarnya adalah penelitian ilmiah. Penelitian dengan pendekatan kualitatif telah memiliki metodologi tersendiri yang berbeda dengan ilmu alam, sehingga masing-masing klaim keilmuan dapat terpenuhi. Penelitian kualitatif memiliki karakteristik sebagai penelitian yang alamiah, tanpa melalui rekayasa eksperimen dan menjadikan manusia sebagai subjek juga objek penelitiannya. Sifatnya yang holistik serta

${ }^{22}$ Sartono Kartodirdjo, Pendekatan Ilmu-Ilmu Sosial dalam Metodologi Sejarah (Jakarta: Gramedia, 1989), 103-6. 
Pendekatan Kualitatif dalam Ilmu Sejarah: Sebuah Telaah Konseptual| Arditya Prayogi

fleksibel juga dengan mekanisme induksi menjadikan kebenaran dalam penelitian kualitatif menjadi sebuah kebenaran relatif.

Sejarah sebagai ilmu humaniora berarti sejarah memiliki metode dan metodologi keilmuannya sendiri yang membedakannya dengan ilmu alam. Perdebatan tentang keilmiahan suatu ilmu turut dijawab sejarah melalui generalisasi. Sifat sejarah yang deskriptif-naratif dan menekankan pada kekuatan bahasa, menghasilkan sebuah generalisasi umum berupa sebuah konsep atau pola dalam sejarah dan turut memengaruhi perkembangan ilmuilmu sosial lain. Generalisasi dalam sejarah tentu tidak berdiri sendiri karena sejarah membutuhkan bantuan ilmu sosial lain dalam ekplanasinya. Pun begitu, sejarah tetaplah sebuah eksplanasi atas peristiwa yang dialami manusia pada masa lampau yang dikonstruksi kembali oleh sejarawan. Hal ini menjadikan unsur subjektivitas tidak dapat dihilangkan dan pada akhirnya menjadikan pendekatan kualitatif menjadi tidak terpisahkan dalam ilmu sejarah.

\section{Daftar Sumber}

Aholiab, Watloly. Tanggung Jawab Pengetahuan: Mempertimbangkan Epistemologi Secara Kultural. Yogyakarta: Kanisius, 2001.

Asba, Rasyid A. Paradigma Baru Perkembangan Teori Dalam Ilmu Sejarah dan Arkeologi. Makalah Bulan Bahasa. Universitas Hassanudin, 2007. Gottschalk, Louis. Mengerti Sejarah. Terj. Nugr. Jakarta: UI Press, 2006. Kartodirdjo, Sartono. Pemikiran dan Perkembangan Historiografi Indonesia : Suatu Alternatif. Jakarta: Gramedia, 1982.

_. Pendekatan Ilmu-Ilmu Sosial dalam Metodologi Sejarah. Jakarta: Gramedia, 1989.

Kholil, Syukur. Metode Penelitian Komunikasi. Jakarta: Gramedia, 2006. Kuntowijoyo. Pengantar Ilmu Sejarah. Yogyakarta: Bentang, 2001.

—. Penjelasan Sejarah. Yogyakarta: Tiara Wacana, 2008.

Muhsin Z, Mumuh. "Urgensitas Analisis Kuantitatif Dalam Penelitian Sejarah". Makalah Seminar Akademik. Jurusan Ilmu Sejarah Universitas Padjadjaran, 2009.

Prayogi, Arditya. "Paradigma Positivisme Dan Idealisme Dalam Ilmu Sejarah: Tinjauan Reflektif Terhadap Posisi Sejarah Sebagai Ilmu." 
Pendekatan Kualitatif dalam Ilmu Sejarah: Sebuah Telaah Konseptual Arditya Prayogi

Tamaddun: Jurnal Kebudayaan dan Sastra Islam 21, no. 1 (2021).

Raco, J.R. Metode Penelitian Kualitatif: Jenis, Karakteristik, dan Keunggulannya. Jakarta: Grasindo, 2007.

Rahmat, Puput Saeful. "Penelitian Kualitatif." Jurnal Equilibrium 5, no. 9 (2009).

Septiawan, Santana K. Menulis Ilmiah: Metode Penelitian Kualitatif. Jakarta: Yayasan Obor, 2007.

Sjamsudin, Helius. Metodologi Sejarah. Yogyakarta: Ombak, 2007.

Supardan, Dadang. Pengantar Ilmu Sosial: Sebuah Kajian Pendekatan Struktural. Jakarta: Bumi Aksara, 2009. 